\title{
Effect of some safety compounds as soil addition and foliar spray treatments on growth and productivity of tomato grown under saline soil conditions
}

\author{
Abo Sedera, F.A., N.S. Shafshak, M.H.M, Mohamed, H.M. Elkoumy* and H.S.S. El- Shafay* \\ Horticulture Dept., Fac. Of Agric., Benha university and * Hort .Res. Institute, Agriculture Research Center, \\ Egypt.
}

\begin{abstract}
Two field experiments were conducted in private sector farm at Elhawa village, Kafr ElSheikh governorate during the summer seasons of 2013 and $2014 \mathrm{on} \mathrm{cv}$. tomato hybrid Morse 44 to elucidate the effect of soil addition and foliar spray of some growth stimulators on improving growth and productivity of tomato grown under saline soil condition. The study included 16 treatments which resulted from the combination of four soil addition treatments included Hummer as a source of humic acid at $(5 \mathrm{~g} / \mathrm{L})$, Double win as a source of seaweed extract at $(5 \mathrm{~g} / \mathrm{L})$ and Freesal as a source of calcium and glutaric acid at $(5 \mathrm{ml} / \mathrm{L})$ in addition to the control treatment via four foliar spray treatments, i.e., Amino power as a source of amino acids at $(1 \mathrm{ml} / \mathrm{L})$., Sward as a source of salicylic acid at $(1 \mathrm{~g} / \mathrm{L})$, monopotassium phosphate at $(1 \mathrm{~g} / \mathrm{L})$ and the control treatments . Results clearly showed that application of soil addition treatments three times in growth season starting 7 days after transplanting and every 10days by intervals reduced the negative effect of soil salinity on measured vegetative growth aspects of tomato plants and increased plant height, number of branches and leaves /plant and fresh and dry weight of plant as well as leaves area compared to the control. In this respect, using seaweed extract exhibited the highest values in all measured growth traits compared with other tested treatments. Also, such treatment increased chlorophyll content, N, P, K, Ca and proline, however it decreased Na concentration in plant foliage compared to the control . In addition, both fruit yield per plant and feddan as well as marketable fruit yield were increased, while unmarketable yield was decreased as a result of soil application treatments . The quality trait of tomato fruits i.e ., average fruit weight, length , diameter, fruit firmness, T.S.S. , vitamin C and total acidity were increased. The highest values were connected with using seaweed extract in both seasons . Spraying the plants with amino acid, monopotassium phosphate and salicylic acid three times during the growing season after 3 weeks from transplanting and every 2 week by intervals tended to alleviate the negative effect of soil salinity and increased all the foregoing vegetative growth measurements, chemical constituents of plant foliage, fruit yield and its components as well as tested physical and chemical fruit quality characters. The highest value in all studied growth, chemical constituents, fruit yield and its quality attributes were recorded in case of using salicylic acid compared to other spray treatments. Also, all the studied interaction treatments significantly enhanced vegetative growth , chemical constituents of plant foliage, fruit yield and its components as well as physical and chemical fruit quality. Treatment included the combination of seaweed extract and salicylic acid was the most effective treatment in this respect.
\end{abstract}

Keywords: Tomato - salinity - humic acid- seaweed extract- amino acids- salicylic acid- monopotassium phosphate

\section{Introduction}

Tomato (Solanum lycopersicum) is one of the most important and wide spread vegetable crops in the world. Its production is limited by many abiotic and biotic stresses. Soil salinity is an important ecological factor because limits nutrition production (Yokoi et al., 2002). In Egypt most of the saline affected soil is located in the northen and middle nile delta as well as its eastern and western sides (Gehad ,2003). Salinity is a well known abiotic factor that affect negatively on vegetative growth traits and productivity of many vegetable crops such as tomato (li,2000,Agong et al., 2004 ;Hajer et al., 2006,Tantawy,2007., Shafshak et al ., 2008).

Tomato is considered moderately sensitive to salt stress, since it can tolerate a pronounced salinity level. yield was not significantly reduced when 4 $\mathrm{dS} / \mathrm{m}$ saline water was applied (Shuqin et al., 2007).
Several recent studies have been made to alleviate the negative effect of salinity on growth and productivity of tomato. In this respect, Eata(2001), Achilea (2002), Ahmed (2003), Ashraf and Ewees (2008) and Shafshak et al.(2008) indicated that application of humic acid and mono potassium phosphate interact the adverse effect on different measured vegetative growth parameters (plant height, number of leaves and branches/plant, fresh and dry weight and leaf area). Also, Eata (2001), Hafez (2001) Economakis and Daskalaki (2003), Chapagain and Wiesman (2004), Neeraja et al.(2005), Shafshak et al. (2008), Fischer et al. (2009), El-Desouky et al.(2011) and Rady (2012) reported that using environmental friendly products such as potassium humate, monopotassium phosphate and amino acids over come the reducing effect of soil salinity and increased chemical constituents of plant foliage $(\mathrm{N}, \mathrm{P}, \mathrm{K}, \mathrm{Ca}$, proline and 
chlorophyll content) and fruit yield and its components as well as improved fruit quality indices . Plant growth hormones, such as salicylic acid can be used to promote growth and yield of plants under various stress conditions including salt stress. salicylic acid is a naturally occurring plant hormone of phenolic nature that has diverse effects on tolerance to abiotic stresses .( Daneshmand, et al ., 2009., Khan et al ., 2010). Zahra et al.(2010) reported that the very important role of salicylic acid in response to different stress and modification and decline damages due to stress has established in different studies so they study the effect of salicylic acid on tomato growth under salinity stress, found that spraying tomato plants with $\mathrm{SA}$ at rate $0,0.5,1$ and $1.5 \mathrm{mM}$ had no effect on root or vegetative growth of tomato plants under salinity stress. Javaheri et al. (2012) studied the effect of 4 concentrations of SA $\left(0^{-2}, 10^{-4}, 10^{-6} \mathrm{M}\right)$ as a foliar spray on plants . Results showed that application of SA at $10^{-6} \mathrm{M}$ significantly had higher fruit yield compared to non treated plant.

Seaweed extract are known as a source of plant growth regulators (Jameson , 1993) organic osmolites , amino acids, mineral nutrients, vitamins and vitamin precursors.(Berlyn and Russo,1990). Seaweed extract as soil conditioning agent it combines with metabolic radicals to form cross-link polymers which increase water holding characteristics of the rhizospherel contributes to create an environment more suitable for the growth of roots and root associated beneficial microorganisms ( Chen et al ., 2003) . Vernieri et al. (2006) . Eyras et al. (2008) Sultana et al. (2009) and Rosalba et al.(2013) studied the effect of seaweed extract as either soil addition or foliar spray on tomato growth . Results indicated that using seaweed extract increased plant vegetative growth traits (plant height, fresh and dry weight of plant) and plant productivity. Seaweed extract have been found to contain significant amount of cytokinins, auxins and betains which influence cell divison a long with the induction of flower formation (Schwab and Raab , 2004). Bynum et al. (2007) indicated that seaweed extract application plus nitrophenolates promoted cell division, flower formation, fruit size and fruits production. Lolaei (2012) studied the effect of calcium chloride on growth of tomato grown under sodium chloride stress. He used four levels $(0,100$, 200 and $300 \mathrm{mg} / \mathrm{L}$ ) and found that increasing $\mathrm{Ca}+$ concentration in nutrient solution increased vegetative growth (plant height, number of leaves and fresh weight ), leaf $\mathrm{Ca}, \mathrm{K}, \mathrm{P}$ and $\mathrm{N}$ content , plant and total fruit yield. Rab and Haq (2012) reported that foliar application of $\mathrm{CaCl} 2,(0.3 \%$ and $0.6 \%$ ) significantly enhanced fruit weight and fruit firmness and decreased the incidence of blossom end rot of tomato fruit. Therefore this study was performed to investigate the effect of using some environmentally friendly growth stimulating compounds as a soil addition (seaweed extract , humic acid, calcium and glutaric acid ) and foliar spray (salicylic acid, amino acid and monopotassium phosphate ) on growth, yield and fruit quality of tomato plants grown under saline soil conditions.

\section{Materials and methods}

Two field experiments were carried out during the two successive summer seasons of 2013 and 2014 in private sector farm at Elhawa village, Kafr El-Sheikh governorate, to investigate the effect of soil addition of humic acid, seaweed extract and calcium plus glutraic acid as well as the foliar spray with amino acids, salicylic acid and monopotassium phosphate on growth, chemical composition, fruit yield and its quality of tomato plants ( Solanum Lycopersicum Mill ) cv. Hybrid Morse 44. The soil of the experimental field was clay in texture with $\mathrm{pH} 7.39$. Soil mechanical and chemical analyses are shown in Table a.

Table a. Average mechanical and chemical analyses of the used soil during the two seasons of growth.

\begin{tabular}{lllclc}
\hline \multirow{2}{*}{ Physical analysis } & & \multicolumn{3}{c}{ Chemical analysis } \\
\cline { 3 - 6 } & & \multicolumn{3}{c}{ Cations meq/l } & \multicolumn{2}{c}{ Anions meq/l } \\
\hline Coarse sand & $18.3 \%$ & $\mathrm{Ca}^{++}$ & 25.4 & $\mathrm{CO}^{--}$ & Zero \\
Fine sand & $12.8 \%$ & $\mathrm{Mg}^{++}$ & 22.10 & $\mathrm{HCO}^{-}$ & 3.6 \\
Silt & $13.5 \%$ & $\mathrm{Na}^{+}$ & 25.13 & $\mathrm{Cl}^{-}$ & 50.0 \\
Clay & $55.4 \%$ & $\mathrm{~K}^{+}$ & 1.87 & $\mathrm{SO}^{--}$ & 20.8 \\
Texture class & clay & & & & \\
Soil pH & 7.39 & Available N & $23.9 \mathrm{mg} / \mathrm{kg}$ \\
E.C, dS/m & 6.86 & Available P & $12.6 \mathrm{mg} / \mathrm{kg}$ \\
\hline Organic matter & $2.6 \%$ & Available K & \multicolumn{3}{c}{$183 \mathrm{mg} / \mathrm{kg}$} \\
\hline
\end{tabular}

The area of the experimental plot was $10.5 \mathrm{~m}^{2}$ included three ridges each 3.5 meters in long and 1 meter in width. Transplanting was done on one side of ridge at $30 \mathrm{~cm}$ apart between transplants.
Transplanting was done on $7^{\text {th }}$ and $9^{\text {th }}$ of March in 2013 and 2014, respectively. The soil addition treatments were added beside plants three times starting 7 days after transplanting and every 10 days 
by intervals. The spray treatments were started after 21 days from transplanting and every 2 weeks by intervals for three times through the growing season. A split plot design with four replicates was used in this experiment where the soil addition treatments were distributed in the main plots while the spray treatments were located randomly in the sub plots. The agricultural practices concerning cultivation, fertilization, irrigation and pest- and disease control were conducted as commonly followed according to the recommendation of the ministry of Agriculture for the commercial production of tomato. This experiments included 16 treatments resulted from the combination between four soil addition treatments and four spray treatments as follows.

\section{a. Soil addition treatments}

1- Hammer as a source of humic acid at $5 \mathrm{~g} / \mathrm{liter}$

2- Double win as a source of seaweed extract as growth stimulator at $5 \mathrm{~g} / 1$.

3- Freesal as a source of calcium and glutraic acid at $5 \mathrm{ml} / 1$.

4- The control treatment (without any addition).

\section{b. Spray treatments.}

1- Amino power as a source of amino acids at $1 \mathrm{ml} / 1$.

2- Sward as a source of salicylic acid at $1 \mathrm{~g} / \mathrm{l}$.

3- Monopotassium phosphate at $1 \mathrm{~g} / \mathrm{l}$.

4-The control treatment (spray with tap water).

Where: Hammer: - is commercial product contain $86 \%$ soluble potassium humate and $6 \% \mathrm{k} 20$

Double win: is commercial product contain seaweed extract $8 \%$ - Organic matter $40 \%$.

Freesal :- is commercial product contain: calcium $11 \%$, Glutraic acid 10\%, Polyethylene glucol $5 \%$,Carbococil organic matter $5 \%$

Amino power:- is commercial product contain $20 \%$ free L. amino acids , $40 \%$ total amino acids , 3\% mix of vitamins and $3.5 \%$ potassium citrate

Sward :- is commercial product contain: Salicylic acid 25\%,,K20 25\%

\section{Data recorded:}

Data on vegetative growth, yield and its components, and physical and chemical fruits characteristics were recorded as follows:

a. Vegetative growth characteristics.

Three plants were taken from each experimental plot as a representative sample after 60 days from transplanting and the following data were recorded. plant length, number of branches and leaves/plant, fresh and dry weight per plant and Leaf area/plant .

\section{b. Chemical composition of plant foliage:}

Total chlorophyll, nitrogen, phosphorus, potassium, calcium, sodium, and proline content were determined according to Pregl (1945), John (1970), Brown and Lilleland (1964), Rowell (1995) and Bates, et al., (1973), respectively. c . Fruit yield and its components:
At harvest mature fruits were picked along the harvesting season and the following data were recorded

Total fruit yield/fed: It was calculated using plot yield and plot area.

Fruit yield/plant: It was calculated form fruit yield/plot and number of plants/plot.

Marketable fruit yield/fed: it was calculated as weight of harvested fruits after discarding the misshaped fruits.

Unmarketable yield /fed: it was calculated as weight of infected and the misshaped fruits.

\section{d. Fruit quality}

1- Physical quality: A random sample of 10 fruits at full ripe stage from each experimental plot was taken to determine the following properties. Average fruit weight, length, diameter and firmness. Fruit firmness $(\mathrm{g} / \mathrm{cm} 2)$ was determined by using digitalis Penetrometer (PCE-PTR.MITPC, USA) with a needle $8 \mathrm{~mm}$ in diameter.

\section{Chemical quality:}

Total soluble solids (T.S.S.): A random sample of 10 fruits from each experimental plot at full ripe stage was taken to determine the percentage of soluble solid content by using the hand refractmeter.

Total titratable acidity (T.T.A) and L.ascorbic acid were determined according to the method described in A. O. A.C. (1990).

\section{Statistical analysis:}

All collected data were subjected to statistical analysis according to Snedecor and Cochran (1991) where the least significant difference was considered when even possible.

\section{Results and Discussion}

\section{1- Vegetative growth characteristics \\ 1.1. Effect of soil addition treatments.}

Concerning the effect of soil addition treatments, data in Table 1 show that addition of each of humic acid at $5 \mathrm{~g} / 1$, seaweed extract at $5 \mathrm{~g} / 1$ and calcium plus glutaric acid at $5 \mathrm{ml} / 1$ three times during the growing season starting 7 days of transplanting and every 10 days by intervals imigated the effect of soil salinity and increased all measured vegetative growth parameters expressed as plant height, number of branches and leaves per plant, fresh and dry weight of plant and leaves area compared with the control treatment. Obtained results are true during both seasons of study. In this connection, addition of seaweed extract reflected the highest values of all studied vegetative growth traits followed by humic acid and calcium plus glutaric acid in descending order .The relative increase in fresh and dry weight as an average of the two seasons were 62.78,78.2 and $27.2 \%$ in case of fresh weight and 17.51,25.82 and 
$24.58 \%$ in case of dry weight over the control as a result of the addition of humic acid, seaweed extract and calcium plus glutaric acid, respectively. In addition, no significant differences among using seaweed extract and humic acid in all the vegetative growth measurements except in case of leaves area during the first season of growth .In this concerned, the increments in different studied vegetative growth aspects as result of using soil addition treatments may be due to the main role of such substance as natural soil conditioner, increasing soil water holding and fertility holding capacity, chelating the nutrient elements and make it more available to absorption by plant, encauraging root growth, source of growth regulators such as cytokinines, gebbraline and oxines, cause the replacement of $\mathrm{Ca}$ and $\mathrm{Mg}$ instead of $\mathrm{Na}$ on the surface of soil particles. As a result of for mentioned effects for such treatments it ameliorate the effect of soil salinity on plant growth and increased the different morphological parameters of plants. Obtained results are in agreement with those reported by Eata(2001), Achilea (2002), Ahmed (2003), Ashraf and Ewees (2008) and Shafshak, et al.(2008) they reported that humic acid had an increasing effect on measured vegetative growth parameters. In addition, Berlyn and Russo (1990), Chen et al.(2003), Vernieri et al. (2006), Eyras et al. (2008), Sultana et al.(2009) and Rosalba et al.(2013) on tomato indicated that seaweed extract significantly increased vegetative growth characteristics of plants. While Rab and Haq (2012), Lolaei (2012) and Abbasl et al. (2013) in case of calcium and glutraic acid on tomato reported similar results.

\subsection{Effect of foliar spray treatments.}

With regard to the effect of foliar spray treatments, the same data in Table 1 indicate that spraying the plants with amino acids at concentration of $1 \mathrm{ml} / 1$, monopotassium phosphate at $1 \mathrm{~g} / \mathrm{l}$ and salicylic acid at $1 \mathrm{~g} / \mathrm{l}$ three times during the growing season starting after three weeks from transplanting and every two weeks by intervals reduced the adverse effect of soil salinity and significantly increased all studied morphological parameters compared with the control treatment during the two seasons of growth. In this concept, spraying the plants with salicylic acid exhibited the highest values in all measured growth traits followed by using monopotassium phosphate and amino acid in descending order. In addition, no significant differences were noticed among the application of salicylic acid and monopotassium phosphate in all determined growth parameters in both seasons of study .In this connecting, the positive effect of salicylic acid on plant growth may be due to salicylic acid was phenolic acid which act as antioxidant and anti-diseases keep the plants more healthy and delaying the senescence and increase resistance of stress of plant which in turn increased plant growth
These results are similar to those reported by Hafez (2001), Economakis and Daskalaki (2003), Naeraja et al.(2005), Shafshak et al.(2008) and El-Desouky et al.(2011) on tomato in case of amino acids, Daneshmand et al .(2009), Khan et al.(2010), Zahra et al. (2010) and Salehi et al. (2011) in case of salicylic acid and Chapagain and Wiesman(2004) and Shafshak et al. (2008) in case of monopotassium phosphate on tomato reported similar results.

\subsection{Effect of the interaction.}

As for the interaction between soil addition and foliar spray treatments, the same data in Table 1 reveal that the highest values in all measured growth traits were recorded as a result of using seaweed extract combined with spraying the plants with salicylic acid in the first season and using calcium plus glutaric acid combined with spraying the plant with amino acid during the second season of growth.

\section{Chemical composition of plant foliage:- \\ 2.1. Effect of soil addition treatments}

Data in Table 2 indicate clearly that addition each of humic acid at a rate of $5 \mathrm{~g} / \mathrm{L}$, seaweed extract at $5 \mathrm{~g} / \mathrm{L}$ and calcium plus glutaric acid at concentration of $5 \mathrm{~m} / \mathrm{L}$ to the soil three times during the growing season starting after 7days from transplanting and every 10 days by intervals significantly increased all assayed chemical constituents of plant foliage i.e., total chlorophyll reading, macro elements ( $\mathrm{N}, \mathrm{P}, \mathrm{K}$ and $\mathrm{Ca}$ percentage) and proline content. However, such treatments significantly decreased sodium concentration in plant foliage compared with the control treatment. Obtained results are true during both seasons of study. In this respect, tomato plants treated with seaweed extract reflected the highest values of all determined chemical constituents followed by those treated with humic acid and calcium plus glutaric acid and lastly, the control plants. Such increases in assayed chemical constituents except sodium which was decreased may be due to the main role of such treatment as soil amendment, increases root growth and its efficiency for absorption to nutrient elements and translocation and accumulations in plant foliage. Also the increases in proline content and reduction in sodium as a result of tested treatments elevate the reducing effect of soil salinity and increased the plant growth. Obtained results are coincided with those reported by Asharf and Ewees (2008), Shafshak et al. (2008), Fisher et al. (2009) and Rady (2012) in case of humic acid and Chen et al.(2003), Vernieri et al. (2006), Eyras et al.(2008), Sultana et al. (2009) and Rosalba et al. (2013)in case of salicylic acid. While Rab and Haq (2012), Lolaei (2012) and Abbasl, et al., (2013) in case of calcium and glutraic acid on tomato reported similar results. 


\subsection{Effect of spray treatments}

With regard to the effect of spray treatments, the same data in Table 2 reveal that all measured chemical constituent i.e., total chlorophyll reading , $\mathrm{N}, \mathrm{P}, \mathrm{K}, \mathrm{Ca}$ and proline content were significantly increased while $\mathrm{Na}$ percentage was significantly decreased as a result of spraying the plants three times during the growing seasons starting after three weeks from transplanting and every 2 weeks by intervals using amino acids at $1 \mathrm{ml} / \mathrm{L}$, monopotassium phosphate at $1 \mathrm{~g} / \mathrm{L}$ and salicylic acid at $1 \mathrm{~g} / \mathrm{L}$. compared with the unsprayed plants the control . In this connection, spraying the plants with salicylic acid recorded the lowest values in sodium and the highest values for other determined chemical constituents compared with other two tested safety compounds and the control one. The increases in assayed chemical constituents as a result of using such tested growth stimulating substances may be attributed to its effect on increasing the vegetative growth inturn increased the capability of plant absorption and assimilation of different chemical constituents. In this respect, similar results were reported on studied vegetable crops by Hafez (2001), Shafshak et al .(2008) and El- Desouky et al. (2011) in case of amino acids and Daneshmand et al .(2009), Khan et al .(2010), Zahra et al.(2010) and Salehi et al.(2011) in case of salicylic acid. While Chapagain and Wiesman(2004) and Shafshak, et al.(2008) in case of monopotassium phosphate

\subsection{Effect of the interaction:}

As for the effect of the interaction between soil addition and spray treatments, the same data in Table 3 show clearly that soil addition treatments especially seaweed extract at $5 \mathrm{~g} / \mathrm{L}$ combined with spraying the plants with salicylic acid at $1 \mathrm{~g} / \mathrm{L}$ reflected the highest values for all measured chemical constituents compared with other interaction treatments during both seasons of growth.

\section{Fruit yield and its components}

\subsection{Effect of soil addition treatments}

Data presented in Table 3 show that total produced fruit yield and its components expressed as fruit yield per plant, marketable and unmarketable fruit yield as well as total fruit yield per feddan were significantly affected as a result of soil addition treatments. In this respect, treatment the soil with each of humic acid at $5 \mathrm{~g} / \mathrm{L}$, seaweed extract at $5 \mathrm{~g} / \mathrm{L}$ and calcium plus glutaric acid at $5 \mathrm{ml} / \mathrm{L}$ three times during the growing seasons starting after 7 days from transplanting and every 10 days by intervals ameliorate the effect of soil salinity and significantly increased fruit yield for both plant and feddan as well marketable fruit yield / fed, however it decreased the un marketable fruit yield compared with the control treatment. In this regard, using seaweed extract as soil addition exhibited the highest values of total fruit yield for both plant and feddan as well as marketable fruit yield compared with other tested treatments in both seasons of study. On the other hand, treatment of calcium plus glutaric acid reflected the lowest value of unmarketable fruit yield. In this connection the relative increases in total fruit yield and marketable yield as a result of soil addition treatments were $14.51,20.3,8.0 \%$ and $16.41,22.74,10.3 \%$ in case of total and marketable yield in first season and $7.78,12.76,5.3$ and 7.75 , $12.82,5.45 \%$ in total and marketable yield in the second season as a result of humic acid, seaweed extract and calcium plus glutaric acid, respectively. Moreover, such increases are connected with increasing the vegetative growth traits Table (1) and increasing the chemical constituents of plant foliage Table 2 which turn affect positively on produced yield. Obtained results are similar to those found by Ashraf and Ewees (2008), Shafshak et al., (2008), Fischer et al., (2009), Rady (2012)in case of humic acid and Chen et al .,(2003), Vernieri et al., (2006), Eyras et al. (2008) Sultana et al. (2009) and Rosalba et al. (2013) in case of seaweed extract as well as Lolaei (2012), Rab and HaQ (2012) in case of calcium and glutraic acid.

\subsection{Effect foliar spray treatments}

Concerning the effect of foliar spray treatments on total fruit yield and its components. The same data in Table 3 indicate that total fruit yield and its components ( fruit yield/ plant and marketable yield) significantly increased while unmarketable yield was decreased as a result of spraying the plants three times during the growing season after 3 week from transplanting and every 2 week by intervals using amino acids at $1 \mathrm{ml} / \mathrm{L}$, monopotassium phosphate $1 \mathrm{~g} / \mathrm{L}$ and salicylic acid at $1 \mathrm{~g} / \mathrm{L}$ compared with the control treatment. In addition, the highest values of fruit yield / plant and / fed. as well as marketable fruit yield/ fed., were obtained as a result of using salicylic acid followed by using monopotassium phosphate and amino acid in a descending order. Furthermore, spraying the plants with salicylic acid reduced the production of unmarketable fruit yield during the two seasons of the experiment. Obtained results are connected with the improvement of plant vegetative growth aspects and the increase in chemical constituents (Tables 1 and 2) which reflected directly on the product ability of plants. In this respect, Hafez (2001), Neeraja et al. (2005), Shafshak et al. (2008) and El- Desouky et al. (2011) in case of amino acids and Daneshmand et al .(2009), Khan et al .(2010), Zahra et al.(2010) and Salehi et al. (2011) in case of salicylic acid, while Chapagain and Wiesman(2004) and Shafshak, et al. (2008) in case of monopotassium phosphate on tomato reported similar results.

\subsection{Effect of the interaction}

With regard to the interaction, Data in Table 3 coincide that addition of seaweed extract at 
$5 \mathrm{~g} / \mathrm{L}$ to the soil combined with spraying the plants three times using salicylic acid at $1 \mathrm{~g} / \mathrm{L}$. reflected the highest values of produced yield for the relative increase in both total and marketable fruit yield as a result of spray treatments were $10.75,15.02,22.98$ $\%$ and $12.45,16.25,25.45 \%$ in case of total and marketable fruit yield in the first season and 5.92, $11.81,18.57$ and $6.55,13.49,22.83$, \% over the control during the second season respectively in case of using amino acids, monopotassium phosphate and salicylic acid in both season plant and fedan as well as marketable fruit yield during the first season and marketable yield and total yield / fed during the second one, In addition, salicylic acid combined with calcium plus glutaric acid produced the higher yield/ plant during the second season. On the other hand, the lowest values of the unmarktable yield were connected with the combination of amino acid with sea weed extract in the first season and salicylic without soil addition (control) in the second season.

\section{Physical fruit quality}

\subsection{Effect of soil addition treatments}

Regarding the effect of soil addition treatments on physical fruit quality of tomato expressed as average fruit weight, length, diameter and fruit firmness, data in Table 4 indicate that all foregoing physical fruit quality traits were significantly increased as a result of soil addition treatments, i.e., humic acid at $5 \mathrm{~g} / \mathrm{L}$ seaweed extract at $5 \mathrm{~g} / \mathrm{L}$ and calcium plus glutaric acid at $5 \mathrm{ml} / \mathrm{L}$. three times during growth season starting 7 days after transplanting and every 10 days by intervals compared to the control treatment. Moreover using seaweed extract reduced the reducing effect of soil salinity and recorded the highest values in all measured physical fruit quality traits compared to the control. In this regard, using humic acid ranks the second and recorded higher values in case of all tested fruit parameter in the first season and fruit weight and firmness in the second one, while the addition of calcium plus glutaric acid exhibited the highest values in case of fruit length and diameter in the second season without significant differences in such tested fruit traits among them during both seasons of study. Such improvement in physical fruit traits as a result of using soil addition treatments may be due to the increase in photosynthetic pigments and mineral elements content except sodium which was decreased (Table 2) which affected positively on plant growth and consequently on quality of produced fruits. In this concept, similar results were reported by Ashraf and Ewees ( 2008), Shafshak et al. (2008), Fischer et al. (2009) in case of humic acid, Chen et al .(2003), Vernieri et al. (2006), Eyras et al. (2008) Sultana et al. (2009) and Rosalba et al. (2013) in case of seaweed extract, While Rab and Haq (2012), Lolaei (2012) and Abbasl et al.(2013) in case of calcium and glutraic acid on tomato reported similar results.

\subsection{Effect of foliar spray treatments}

As for the effect of foliar spray treatments the same data in Table 4 reveal that spraying the plants with amino acid at $1 \mathrm{ml} / \mathrm{L}$, monopotassium phosphate at $1 \mathrm{~g} / \mathrm{L}$ and salicylic acid at $1 \mathrm{~g} / \mathrm{L}$ three times during the growth the season after 3 weeks from transplanting and every 2 weeks by intervals significantly increased all determined fruit quality traits (average fruit weight, length, diameter and fruit firmness) compared to the control treatment obtained results were similar during the two seasons of study. In addition using salicylic acid exhibited the highest values in all tested physical fruit quality traits followed by monopotassium phosphate without significant differences among them in most studied fruit traits. The superiority of salicylic acid in this respect may be due to its role as antioxidant and antidiseases substances which keep plant healthy and vigor and consequently increased its productivity and fruit quality. Similar finding were reported by $\mathrm{Hafez}$ ( 2001), Neeraja et al.(2005), Shafshak et al.(2008), El Desouky et al.( 2011) in case of amino acids, Daneshmand et al .(2009), Khan et al .(2010), Zahra et al. (2010) and Salehi et al.(2011) in case of salicylic acid and Chapagain and Wiesman (2004), Shafshak et al. ( 2008) in case of monopotassium phosphate.

\subsection{Effect of the interaction}

As for the effect of the interaction, data in Table 4 indicate that the highest values in all measured physical fruit quality traits were obtained as a result of using sea weed extract as soil addition combined with spraying the plants with salicylic acid compared with other interaction treatments. Obtained results are true during both seasons of growth.

\section{Chemical fruit quality}

\subsection{Effect of soil addition treatments}

Data presented in Table 5 illustrate the effect of soil addition treatments i.e. humic acid at $5 \mathrm{~g} / \mathrm{L}$ seaweed extract at $5 \mathrm{~g} / \mathrm{L}$ and calcium plus glutaric acid at $5 \mathrm{ml} / \mathrm{L}$ on chemical fruit quality indices of tomato plants grown in saline soil expressed as T.S.S $\%$, vitamin $\mathrm{C}$. content and total acidity percentage during the two seasons of study. In this respect, addition of such treatments to the soil three times during the growth season starting 7 days after transplanting and every 10 days by intervals reduced the decrement effect of soil salinity and significantly increased all determined fruit chemical constituents in both seasons of study compared the untreated treatment . 
Table 1. Effect of some soil addition, foliar spray treatments and their interaction on vegetative growth characteristics of tomato plants grown under saline soil condition during both seasons of study.

\begin{tabular}{|c|c|c|c|c|c|c|c|c|c|c|c|c|c|}
\hline \multicolumn{2}{|c|}{ Treatments } & \multicolumn{6}{|c|}{ Season 2013} & \multicolumn{6}{|c|}{ Season 2014} \\
\hline Soil addition & Foliar spray & $\begin{array}{c}\text { Plant } \\
\text { height } \\
(\mathrm{cm})\end{array}$ & $\begin{array}{c}\text { No. of } \\
\text { branches/ } \\
\text { plant }\end{array}$ & $\begin{array}{c}\text { No. of } \\
\text { leaves/ } \\
\text { plant }\end{array}$ & $\begin{array}{c}\text { Fresh } \\
\text { weight } \\
\text { (g) }\end{array}$ & $\begin{array}{c}\text { Dry } \\
\text { weight } \\
\text { (g) }\end{array}$ & $\begin{array}{c}\text { Leaves } \\
\text { area } \\
(\mathrm{cm})\end{array}$ & $\begin{array}{c}\text { Plant } \\
\text { height } \\
\text { (cm) }\end{array}$ & $\begin{array}{c}\text { No. of } \\
\text { branches/plant }\end{array}$ & $\begin{array}{c}\text { No. of } \\
\text { leaves/ } \\
\text { Plant }\end{array}$ & $\begin{array}{c}\text { Fresh } \\
\text { weight } \\
\text { (g) }\end{array}$ & $\begin{array}{c}\text { Dry } \\
\text { weight } \\
\text { (g) }\end{array}$ & $\begin{array}{c}\text { Leaves } \\
\text { area } \\
(\mathrm{cm})\end{array}$ \\
\hline \multicolumn{2}{|l|}{ Humic acid } & 65.14 & 6.23 & 42.90 & 256.9 & 37.19 & 1141 & 76.91 & 5.17 & 39.31 & 391.5 & 68.66 & 5801 \\
\hline \multicolumn{2}{|l|}{ Seaweed extract } & 66.52 & 6.34 & 44.33 & 292.6 & 38.12 & 1343 & 79.47 & 5.27 & 40.25 & 436.2 & 68.78 & 6149 \\
\hline \multicolumn{2}{|c|}{$\begin{array}{l}\text { Calcium and glutraic } \\
\text { acid }\end{array}$} & 63.44 & 5.61 & 42.77 & 245.1 & 35.91 & 1076 & 77.92 & 5.18 & 40.22 & 417.6 & 69.94 & 6115 \\
\hline \multicolumn{2}{|l|}{ Control } & 55.94 & 5.31 & 36.53 & 129.4 & 17.50 & 723 & 76.18 & 5.01 & 37.88 & 381.8 & 67.47 & 5681 \\
\hline \multirow{2}{*}{\multicolumn{2}{|c|}{ LSD at $5 \%$}} & 2.01 & 0.39 & 3.28 & 3.90 & 1.32 & 21 & 1.25 & 0.31 & 2.63 & 6.63 & 1.72 & 86 \\
\hline & Amino acids & 62.10 & 5.73 & 41.38 & 238.3 & 33.03 & 1029 & 78.43 & 5.42 & 40.77 & 437.5 & 70.41 & 6228 \\
\hline \multicolumn{2}{|r|}{$\begin{array}{l}\text { Monopotassium } \\
\text { phosphate }\end{array}$} & 62.70 & 5.74 & 42.26 & 236.3 & 33.02 & 1051 & 76.60 & 4.91 & 38.35 & 397.1 & 67.92 & 5786 \\
\hline \multicolumn{2}{|r|}{ Salicylic acid } & 65.32 & 6.43 & 44.96 & 240.1 & 34.10 & 1182 & 79.01 & 5.44 & 40.69 & 431.6 & 71.13 & 6271 \\
\hline \multicolumn{2}{|r|}{ Control } & 60.93 & 5.60 & 37.93 & 209.2 & 29.92 & 1023 & 76.44 & 4.87 & 37.24 & 370.9 & 65.4 & 5461 \\
\hline \multicolumn{2}{|l|}{ LSD at 5\% } & 1.76 & 0.53 & 3.18 & 2.92 & 1.81 & 14 & 1.74 & 0.22 & 2.12 & 4.45 & 1.93 & 49 \\
\hline \multirow[t]{4}{*}{ Humic acid } & Amino acids & 66.43 & 6.10 & 42.53 & 269.1 & 35.03 & 1153 & 76.77 & 5.40 & 35.77 & 361.1 & 69.85 & 5314 \\
\hline & $\begin{array}{l}\text { Monopotassium } \\
\text { phosphate }\end{array}$ & 65.96 & 6.20 & 49.95 & 281.3 & 39.88 & 1224 & 74.66 & 5.30 & 39.83 & 402.7 & 70.04 & 6184 \\
\hline & Salicylic acid & 67.63 & 7.25 & 44.30 & 259.9 & 37.20 & 1097 & 80.22 & 5.25 & 42.97 & 433.9 & 73.43 & 6770 \\
\hline & Control & 60.55 & 5.40 & 34.82 & 217.4 & 33.66 & 1091 & 76.00 & 4.75 & 38.66 & 358.1 & 61.32 & 4938 \\
\hline \multirow{4}{*}{ Seaweed extract } & Amino acids & 62.63 & 6.25 & 43.97 & 305.6 & 37.42 & 1302 & 81.22 & 5.40 & 44.43 & 496.6 & 72.35 & 7670 \\
\hline & $\begin{array}{l}\text { Monopotassium } \\
\text { phosphate }\end{array}$ & 66.63 & 6.27 & 43.30 & 304.3 & 38.60 & 1322 & 75.33 & 5.10 & 37.00 & 404.1 & 68.13 & 5231 \\
\hline & Salicylic acid & 71.30 & 6.95 & 51.20 & 326.0 & 41.03 & 1450 & 79.33 & 5.60 & 39.41 & 449.1 & 69.01 & 5916 \\
\hline & Control & 65.53 & 5.90 & 38.85 & 234.6 & 34.42 & 1297 & 82.00 & 5.00 & 40.16 & 395.0 & 65.65 & 5781 \\
\hline \multirow{4}{*}{$\begin{array}{l}\text { Calcium and } \\
\text { glutraic acid }\end{array}$} & Amino acids & 63.50 & 6.10 & 41.20 & 247.2 & 34.40 & 1074 & 78.66 & 5.95 & 45.33 & 430.3 & 74.55 & 7090 \\
\hline & $\begin{array}{l}\text { Monopotassium } \\
\text { phosphate }\end{array}$ & 64.43 & 5.65 & 40.05 & 226.7 & 35.19 & 1005 & 78.42 & 5.00 & 37.75 & 386.7 & 68.43 & 5451 \\
\hline & Salicylic acid & 63.62 & 5.72 & 45.63 & 256.9 & 37.70 & 1439 & 76.83 & 5.07 & 40.25 & 424.0 & 70.48 & 6387 \\
\hline & Control & 62.22 & 5.00 & 39.56 & 249.4 & 32.40 & 988 & 77.77 & 4.73 & 37.57 & 351.4 & 66.32 & 5533 \\
\hline \multirow[t]{4}{*}{ Control } & Amino acids & 55.83 & 4.65 & 37.82 & 131.2 & 17.82 & 763 & 77.05 & 4.95 & 37.54 & 326.0 & 72.89 & 4838 \\
\hline & $\begin{array}{l}\text { Monopotassium } \\
\text { phosphate }\end{array}$ & 53.76 & 4.85 & 35.72 & 132.9 & 16.42 & 870 & 78.00 & 4.65 & 36.86 & 339.2 & 68.10 & 6279 \\
\hline & Salicylic acid & 58.73 & 5.82 & 38.72 & 135.4 & 18.70 & 841 & 79.66 & 5.85 & 40.11 & 362.2 & 71.60 & 6013 \\
\hline & Control & 55.43 & 4.25 & 33.85 & 117.9 & 17.10 & 715 & 70.00 & 4.62 & 37.00 & 300.9 & 57.29 & 5593 \\
\hline \multicolumn{2}{|l|}{ LSD at 5\% } & 3.52 & 1.07 & 6.36 & 7.23 & 3.74 & 29 & 3.48 & $\overline{0.45}$ & 4.25 & 8.72 & 3.96 & 98 \\
\hline
\end{tabular}


Table 2. Effect of soil addition, foliar spray treatments and their interaction on chemical constituent of plant foliage of tomato plants grown under saline soil condition during both seasons of study.

\begin{tabular}{|c|c|c|c|c|c|c|c|c|c|c|c|c|c|c|c|}
\hline \multicolumn{2}{|c|}{ Treatments } & \multicolumn{7}{|c|}{ Season 2013} & \multicolumn{7}{|c|}{ Season 2014} \\
\hline Soil addition & Foliar spray & $\begin{array}{c}\text { Total } \\
\text { chlorophyll }\end{array}$ & $\mathrm{N} \%$ & $\mathrm{P} \%$ & $\mathrm{~K} \%$ & $\mathrm{Ca} \%$ & $\begin{array}{l}\mathrm{Na} \\
\%\end{array}$ & Proline $(\mathrm{mg} / 100 \mathrm{~g})$ & $\begin{array}{c}\text { Total } \\
\text { chlorophyll }\end{array}$ & $\mathrm{N} \%$ & $\mathrm{P} \%$ & $\mathrm{~K} \%$ & $\mathrm{Ca} \%$ & $\begin{array}{l}\mathrm{Na} \\
\%\end{array}$ & Proline $(\mathrm{mg} / 100 \mathrm{~g})$ \\
\hline Humic acid & & 81.50 & 2.38 & 0.173 & 1.21 & 7.29 & 1.66 & 8.33 & 55.01 & 2.35 & 0.191 & 1.65 & 6.72 & 1.62 & 8.18 \\
\hline $\begin{array}{l}\text { Seaweed } \\
\text { extract }\end{array}$ & & 89.61 & 2.43 & 0.174 & 1.45 & 7.36 & 1.61 & 9.44 & 57.29 & 2.66 & 0.192 & 1.74 & 7.30 & 1.57 & 9.82 \\
\hline $\begin{array}{l}\text { Calcium and } \\
\text { glutraic acid }\end{array}$ & & 78.43 & 2.31 & 0.170 & 1.34 & 6.66 & 1.72 & 7.75 & 54.32 & 2.31 & 0.163 & 1.64 & 6.59 & 1.68 & 9.11 \\
\hline Control d & & 63.85 & 2.21 & 0.164 & 1.32 & 6.36 & 1.78 & 6.36 & 53.57 & 2.21 & 0.159 & 1.38 & 6.36 & 1.75 & 7.13 \\
\hline LSD at $5 \%$ & & 3.69 & 0.14 & 0.001 & 0.12 & 0.29 & 0.06 & 0.22 & 2.27 & 0.25 & 0.002 & 0.13 & 0.32 & 0.05 & 0.02 \\
\hline & Amino acids & 75.31 & 2.33 & 0.184 & 1.29 & 6.86 & 1.72 & 8.07 & 55.40 & 2.21 & 0.191 & 1.44 & 6.68 & 1.57 & 8.53 \\
\hline & $\begin{array}{l}\text { Monopotassium } \\
\text { phosphate }\end{array}$ & 81.07 & 2.23 & 0.170 & 1.33 & 6.61 & 1.70 & 7.77 & 55.03 & 2.58 & 0.183 & 1.70 & 6.66 & 1.70 & 8.31 \\
\hline & Salicylic acid & 81.61 & 2.51 & 0.189 & 1.36 & 7.47 & 1.67 & 9.19 & 55.71 & 2.76 & 0.193 & 1.87 & 7.16 & 1.55 & 10.15 \\
\hline & Control & 75.39 & 2.26 & 0.139 & 1.34 & 6.73 & 1.73 & 6.81 & 54.06 & 2.00 & 0.138 & 1.42 & 6.46 & 1.73 & 7.25 \\
\hline LSD at $5 \%$ & & 3.16 & 0.12 & 0.001 & 0.13 & 0.35 & 0.06 & 0.18 & 1.69 & 0.17 & 0.002 & 0.12 & 0.21 & 0.05 & 0.04 \\
\hline Humic acid & Amino acids & ח9 79 & 252 & 0161 & 15 & 672 & 169 & 824 & 5560 & 250 & 0201 & 160 & 672 & 164 & 017 \\
\hline & Monopotassium & & & & & & & & & & & & & & \\
\hline & phosphate & $\begin{array}{l}80.47 \\
83.13\end{array}$ & $\begin{array}{l}2.30 \\
2.60\end{array}$ & $\begin{array}{l}0.162 \\
0182\end{array}$ & $\begin{array}{l}1.24 \\
131\end{array}$ & $\begin{array}{l}6.72 \\
7.72\end{array}$ & $\begin{array}{l}1.64 \\
158\end{array}$ & $\begin{array}{l}8.16 \\
975\end{array}$ & $\begin{array}{l}54.92 \\
5672\end{array}$ & $\begin{array}{l}2.40 \\
2.70\end{array}$ & $\begin{array}{l}0.185 \\
0225\end{array}$ & $\begin{array}{l}1.76 \\
1.93\end{array}$ & $\begin{array}{l}6.72 \\
7.22\end{array}$ & $\begin{array}{l}1.71 \\
1.46\end{array}$ & $\begin{array}{l}8.93 \\
1056\end{array}$ \\
\hline & Control & 71.80 & 2.12 & 0.133 & 1.14 & 6.50 & 1.73 & 7.05 & 52.80 & 2.31 & 0.156 & 1.32 & 6.22 & 1.79 & 7.81 \\
\hline Seaweed & Amino acids & 98.18 & 2.50 & 0.163 & 1.53 & 7.50 & 1.68 & 9.47 & 58.13 & 2.60 & 0.192 & 1.69 & 7.00 & 1.60 & 9.74 \\
\hline extract & $\begin{array}{l}\text { Monopotassium } \\
\text { phosphate }\end{array}$ & 84.20 & 2.41 & 0.179 & 1.37 & 7.00 & 1.60 & 9.07 & 56.83 & 2.82 & 0.221 & 1.77 & 7.50 & 1.70 & 9.38 \\
\hline & Salicylic acid & 106.40 & 2.80 & 0.194 & 1.75 & 8.22 & 1.52 & 10.92 & 58.30 & 2.97 & 0.225 & 1.90 & 8.22 & 1.43 & 11.65 \\
\hline & Control & 76.55 & 2.20 & 0.123 & 1.15 & 6.72 & 1.73 & 8.33 & 55.93 & 2.22 & 0.134 & 1.63 & 6.50 & 1.76 & 8.52 \\
\hline Calcium and & Amino acids & 79.30 & 2.13 & 0.170 & 1.39 & 7.22 & 1.76 & 7.86 & 54.03 & 2.42 & 0.153 & 1.61 & 6.50 & 1.62 & 8.12 \\
\hline glutraic acid & $\begin{array}{l}\text { Monopotassium } \\
\text { phosphate }\end{array}$ & 79.00 & 2.40 & 0.169 & 1.33 & 7.00 & 1.71 & 7.52 & 54.03 & 2.62 & 0.175 & 1.47 & 6.42 & 1.65 & 7.99 \\
\hline & Salicylic acid & 91.28 & 2.62 & 0.180 & 1.42 & 8.22 & 1.59 & 8.96 & 55.00 & 2.60 & 0.193 & 2.27 & 7.22 & 1.51 & 9.58 \\
\hline & Control & 74.93 & 2.15 & 0.163 & 1.24 & 5.72 & 1.83 & 6.64 & 54.22 & 2.38 & 0.134 & 1.24 & 6.22 & 1.78 & 7.05 \\
\hline Control & Amino acids & 66.53 & 2.22 & 0.179 & 1.28 & 6.72 & 1.77 & 6.72 & 52.72 & 2.32 & 0.171 & 1.23 & 6.50 & 1.82 & 7.12 \\
\hline & $\begin{array}{l}\text { Monopotassium } \\
\text { phosphate }\end{array}$ & 66.25 & 2.20 & 0.168 & 1.33 & 6.00 & 1.76 & 6.35 & 55.03 & 2.50 & 0.153 & 1.57 & 6.00 & 1.79 & 6.95 \\
\hline & Salicylic acid & 72.80 & 2.32 & 0.180 & 1.62 & 7.00 & 1.63 & 7.15 & 57.70 & 2.72 & 0.181 & 1.63 & 6.72 & 1.70 & 8.81 \\
\hline & Control & 56.53 & 2.12 & 0.131 & 1.05 & 5.72 & 1.94 & 5.22 & 48.83 & 2.05 & 0.131 & 1.12 & 6.22 & 1.98 & 5.64 \\
\hline LSD at $5 \%$ & & 6.33 & 0.25 & 0.001 & 0.27 & 0.71 & 0.13 & 0.37 & 3.38 & 0.35 & 0.004 & 0.25 & 0.42 & 0.10 & 0.09 \\
\hline
\end{tabular}


Table 3. Effect of some soil addition, foliar spray treatments and their interaction on fruit yield and its component of tomato plants grown under saline soil condition during both seasons of study.

\begin{tabular}{|c|c|c|c|c|c|c|c|c|c|}
\hline \multicolumn{2}{|c|}{ Treatments } & \multicolumn{4}{|c|}{ Season 2013} & \multicolumn{4}{|c|}{ Season 2014} \\
\hline Soil addition & Foliar spray & $\begin{array}{l}\text { Total yield } \\
\text { (kg /plant) }\end{array}$ & $\begin{array}{l}\text { Total yield } \\
\text { (t/ fed.) }\end{array}$ & $\begin{array}{c}\text { Marketable } \\
\text { yield } \\
\text { (t/ fed.) }\end{array}$ & $\begin{array}{c}\text { Unmarketable } \\
\text { yield } \\
\text { (t/ fed.) }\end{array}$ & $\begin{array}{l}\text { Total yield } \\
\text { (kg/plant) }\end{array}$ & $\begin{array}{l}\text { Total yield } \\
\text { (t/ fed.) }\end{array}$ & $\begin{array}{c}\text { Marketable } \\
\text { yield } \\
\text { (t/ fed.) }\end{array}$ & $\begin{array}{c}\text { Unmarketable } \\
\text { yield } \\
\text { (t/ fed.) }\end{array}$ \\
\hline Humic acid & & 5.66 & 42.47 & 39.71 & 2.76 & 4.87 & 36.56 & 33.20 & 3.36 \\
\hline Seaweed extract & & 5.94 & 44.62 & 41.87 & 2.75 & 5.12 & 38.25 & 34.76 & 3.47 \\
\hline Calcium and glutraic acid & & 5.33 & 40.06 & 37.63 & 2.35 & 4.75 & 35.72 & 32.49 & 3.23 \\
\hline Control & & 4.94 & 37.09 & 34.11 & 3.04 & 4.51 & 33.92 & 30.81 & 3.10 \\
\hline \multirow[t]{5}{*}{ LSD at $5 \%$} & & 0.15 & 1.15 & 0.51 & 0.15 & 0.13 & 0.88 & 0.73 & 0.10 \\
\hline & Amino acids & 5.42 & 40.74 & 37.92 & 2.81 & 4.69 & 35.07 & 31.55 & 3.52 \\
\hline & Monopotassium phosphate & 5.59 & 42.03 & 39.20 & 2.89 & 4.93 & 37.02 & 33.74 & 3.26 \\
\hline & Salicylic acid & 5.98 & 44.94 & 42.47 & 2.53 & 5.23 & 39.26 & 36.37 & 2.89 \\
\hline & Control & 4.86 & 36.54 & 33.72 & 2.69 & 4.41 & 33.11 & 29.61 & 3.50 \\
\hline LSD at $5 \%$ & & 0.12 & 0.96 & 0.81 & 0.11 & 0.10 & 0.80 & 0.71 & 0.12 \\
\hline \multirow[t]{4}{*}{ Humic acid } & Amino acids & 5.53 & 41.52 & 38.20 & 3.32 & 4.67 & 35.12 & 31.56 & 3.56 \\
\hline & Monopotassium phosphate & 5.88 & 44.14 & 41.36 & 2.78 & 4.98 & 37.43 & 34.15 & 3.28 \\
\hline & Salicylic acid & 6.32 & 47.42 & 44.80 & 2.60 & 5.29 & 39.75 & 36.98 & 2.77 \\
\hline & Control & 4.90 & 36.82 & 34.46 & 2.36 & 4.52 & 33.95 & 30.12 & 3.83 \\
\hline \multirow[t]{4}{*}{ Seaweed extract } & Amino acids & 5.78 & 43.4 & 41.56 & 1.84 & 4.59 & 37.52 & 33.25 & 4.27 \\
\hline & Monopotassium phosphate & 5.98 & 44.9 & 42.23 & 2.67 & 4.90 & 38.97 & 35.05 & 3.87 \\
\hline & Salicylic acid & 6.64 & 49.88 & 46.75 & 3.13 & 5.19 & 41.76 & 38.93 & 2.83 \\
\hline & Control & 5.37 & 40.3 & 36.92 & 3.38 & 4.34 & 34.75 & 31.82 & 2.93 \\
\hline \multirow[t]{4}{*}{ Calcium and glutraic acid } & Amino acids & 5.44 & 40.9 & 38.11 & 2.75 & 5.09 & 34.47 & 31.09 & 3.38 \\
\hline & Monopotassium phosphate & 5.47 & 41.2 & 38.95 & 2.50 & 5.19 & 36.82 & 33.92 & 2.90 \\
\hline & Salicylic acid & 5.64 & 42.35 & 40.12 & 2.24 & 5.56 & 38.98 & 35.20 & 3.78 \\
\hline & Control & 4.76 & 35.79 & 33.35 & 1.94 & 4.63 & 32.63 & 29.76 & 2.87 \\
\hline \multirow[t]{4}{*}{ Control } & Amino acids & 4.94 & 37.15 & 33.82 & 3.34 & 4.41 & 33.15 & 30.28 & 2.87 \\
\hline & Monopotassium phosphate & 5.04 & 37.87 & 34.25 & 3.62 & 4.64 & 34.86 & 31.86 & 3.00 \\
\hline & Salicylic acid & 5.34 & 40.1 & 38.20 & 2.15 & 4.87 & 36.56 & 34.36 & 2.18 \\
\hline & Control & 4.40 & 33.25 & 30.17 & 3.08 & 4.14 & 31.12 & 26.75 & 4.37 \\
\hline LSD at $5 \%$ & & 0.25 & 1.93 & 1.63 & 0.66 & 0.21 & 1.61 & 1.42 & 0.61 \\
\hline
\end{tabular}


Table 4. Effect of some soil addition, foliar spray treatments and their interaction on physical fruit quality of tomato fruits during both season of study.

\begin{tabular}{|c|c|c|c|c|c|c|c|c|c|}
\hline \multicolumn{2}{|c|}{ Treatments } & \multicolumn{4}{|c|}{ Season 2013} & \multicolumn{4}{|c|}{ Season 2014} \\
\hline Soil addition & Foliar spray & $\begin{array}{c}\text { Average } \\
\text { fruit } \\
\text { weight(g) }\end{array}$ & $\begin{array}{c}\text { Fruit } \\
\text { length }(\mathbf{c m})\end{array}$ & $\begin{array}{c}\text { Fruit } \\
\text { diameter } \\
(\mathbf{c m})\end{array}$ & $\begin{array}{l}\text { Fruit } \\
\text { firmness } \\
(\mathrm{g} / \mathrm{cm} 2)\end{array}$ & $\begin{array}{c}\text { Average } \\
\text { fruit } \\
\text { weight(g) }\end{array}$ & $\begin{array}{c}\text { Fruit } \\
\text { length(cm) }\end{array}$ & $\begin{array}{c}\text { Fruit } \\
\text { diameter } \\
(\mathrm{cm})\end{array}$ & $\begin{array}{l}\text { Fruit } \\
\text { firmness } \\
(\mathrm{g} / \mathrm{cm} 2)\end{array}$ \\
\hline \multicolumn{2}{|l|}{ Humic acid } & 156.9 & 5.63 & 6.59 & 3.63 & 168.7 & 5.18 & 6.33 & 1.96 \\
\hline \multirow{2}{*}{\multicolumn{2}{|c|}{$\begin{array}{l}\text { Seaweed extract } \\
\text { Calcium and glutraic acid }\end{array}$}} & 181.9 & 5.81 & 6.71 & 3.83 & 181.4 & 5.32 & 6.55 & 2.01 \\
\hline & & 146.8 & 5.60 & 6.50 & 3.58 & 165.2 & 5.26 & 6.48 & 1.92 \\
\hline \multicolumn{2}{|l|}{ Control } & 133.9 & 5.33 & 6.42 & 3.31 & 158.5 & 4.96 & 6.30 & 1.88 \\
\hline \multicolumn{2}{|l|}{ LSD at $5 \%$} & 2.2 & 0.11 & 0.10 & 0.11 & 1.9 & 0.21 & 0.46 & 0.14 \\
\hline \multirow{2}{*}{\multicolumn{2}{|c|}{$\begin{array}{l}\text { Amino acids } \\
\text { Monopotassium phosphate }\end{array}$}} & 153.9 & 5.56 & 6.56 & 3.51 & 172.9 & 5.11 & 6.40 & 1.85 \\
\hline & & 154.7 & 5.64 & 6.53 & 3.62 & 170.8 & 5.20 & 6.46 & 1.91 \\
\hline \multirow{2}{*}{\multicolumn{2}{|c|}{$\begin{array}{l}\text { Salicylic acid } \\
\text { Control }\end{array}$}} & 157.5 & 5.88 & 6.78 & 3.70 & 175.7 & 5.43 & 6.59 & 2.30 \\
\hline & & 133.5 & 5.29 & 6.33 & 3.53 & 154.6 & 4.98 & 6.21 & 1.72 \\
\hline \multicolumn{2}{|c|}{ LSD at $5 \%$} & 1.3 & 0.12 & 0.18 & 0.18 & 1.7 & 0.19 & 0.24 & 0.12 \\
\hline \multirow[t]{4}{*}{ Humic acid } & Amino acids & 116.6 & 5.65 & 6.62 & 3.59 & 155.5 & 5.20 & 6.37 & 2.08 \\
\hline & Monopotassium phosphate & 144.4 & 5.65 & 6.52 & 3.59 & 183.3 & 5.27 & 6.30 & 1.92 \\
\hline & Salicylic acid & 153.3 & 5.75 & 7.02 & 3.88 & 191.6 & 5.35 & 6.47 & 2.25 \\
\hline & Control & 133.3 & 5.55 & 6.20 & 3.52 & 144.4 & 4.92 & 6.20 & 1.60 \\
\hline \multirow[t]{4}{*}{ Seaweed extract } & Amino acids & 181.1 & 5.80 & 6.72 & 3.99 & 191.6 & 5.20 & 6.62 & 1.82 \\
\hline & Monopotassium phosphate & 183.3 & 5.72 & 6.72 & 3.89 & 166.6 & 5.50 & 6.82 & 2.22 \\
\hline & Salicylic acid & 208.1 & 6.15 & 6.80 & 4.35 & 200.0 & 5.60 & 6.90 & 2.32 \\
\hline & Control & 155.0 & 5.57 & 6.52 & 3.11 & 165.5 & 5.00 & 5.60 & 1.70 \\
\hline \multirow[t]{4}{*}{ Calcium and glutraic acid } & Amino acids & 138.9 & 5.62 & 6.43 & 3.47 & 158.3 & 5.32 & 6.70 & 1.80 \\
\hline & Monopotassium phosphate & 155.5 & 5.60 & 6.40 & 3.51 & 175.0 & 5.20 & 6.42 & 1.90 \\
\hline & Salicylic acid & 155.5 & 5.97 & 6.77 & 3.74 & 177.7 & 5.35 & 6.75 & 2.20 \\
\hline & Control & 137.5 & 5.22 & 6.35 & 3.42 & 150.0 & 5.17 & 6.35 & 1.80 \\
\hline \multirow[t]{4}{*}{ Control } & Amino acids & 140.8 & 5.35 & 6.50 & 3.42 & 161.1 & 4.80 & 6.10 & 1.80 \\
\hline & Monopotassium phosphate & 135.5 & 5.60 & 6.25 & 3.32 & 158.3 & 4.80 & 6.42 & 1.72 \\
\hline & Salicylic acid & 151.0 & 5.65 & 6.75 & 3.46 & 177.7 & 5.52 & 6.65 & 2.42 \\
\hline & Control & 108.3 & 4.72 & 5.85 & 3.06 & 137.0 & 4.72 & 6.02 & 1.60 \\
\hline \multicolumn{2}{|l|}{ LSD at $5 \%$} & 2.6 & 0.24 & 0.36 & 0.37 & 3.9 & 0.38 & 0.49 & 0.25 \\
\hline
\end{tabular}


Table 5. Effect of some soil addition, foliar spray treatments and their interaction on chemical fruit quality of tomato fruits during both season of study.

\begin{tabular}{|c|c|c|c|c|c|c|c|}
\hline \multirow{2}{*}{$\begin{array}{l}\text { Treatments } \\
\text { Soil addition }\end{array}$} & \multirow[b]{2}{*}{ Foliar spray } & & \multirow{2}{*}{$\begin{array}{c}\text { Season } 2013 \\
\text { V. C mg/100 g }\end{array}$} & \multirow{2}{*}{ - } & \multicolumn{3}{|c|}{ Season 2014} \\
\hline & & T.S.S \% & & & T.S.S \% & V. C mg/100 g & Acidity \% \\
\hline Humic acid & & 6.99 & 39.39 & 1.40 & 6.92 & 38.43 & 1.87 \\
\hline Seaweed extract & & 7.10 & 41.04 & 1.60 & 7.18 & 40.43 & 2.22 \\
\hline Calcium and glutraic acid & & 7.05 & 40.45 & 1.35 & 7.57 & 39.54 & 1.74 \\
\hline Control & & 6.98 & 36.79 & 0.97 & 6.76 & 37.70 & 1.31 \\
\hline \multirow[t]{5}{*}{ LSD at $5 \%$} & & 0.10 & 1.19 & 0.53 & 0.18 & 1.71 & 0.20 \\
\hline & Amino acids & 7.02 & 39.67 & 1.18 & 7.41 & 39.67 & 1.73 \\
\hline & Monopotassium phosphate & 7.02 & 38.91 & 1.37 & 7.25 & 38.37 & 1.86 \\
\hline & Salicylic acid & 7.08 & 41.68 & 1.74 & 7.18 & 40.18 & 2.00 \\
\hline & Control & 7.01 & 37.39 & 1.03 & 6.60 & 37.88 & 1.54 \\
\hline LSD at $5 \%$ & & 0.06 & 1.65 & 0.41 & 0.33 & 1.47 & 0.11 \\
\hline \multirow[t]{4}{*}{ Humic acid } & Amino acids & 7.00 & 40.33 & 1.27 & 7.80 & 40.00 & 1.70 \\
\hline & Monopotassium phosphate & 7.01 & 40.26 & 1.75 & 7.10 & 36.50 & 2.00 \\
\hline & Salicylic acid & 7.02 & 41.65 & 1.80 & 7.32 & 41.00 & 2.10 \\
\hline & Control & 6.96 & 35.33 & 0.80 & 6.52 & 36.23 & 1.70 \\
\hline \multirow[t]{4}{*}{ Seaweed extract } & Amino acids & 7.00 & 39.40 & 1.60 & 7.80 & 40.24 & 2.32 \\
\hline & Monopotassium phosphate & 7.10 & 42.75 & 1.47 & 7.80 & 42.01 & 2.22 \\
\hline & Salicylic acid & 7.20 & 44.00 & 2.35 & 7.30 & 42.17 & 2.30 \\
\hline & Control & 7.12 & 38.00 & 0.97 & 7.40 & 37.30 & 2.05 \\
\hline \multirow[t]{4}{*}{ Calcium and glutraic acid } & Amino acids & 7.10 & 41.33 & 1.75 & 7.30 & 40.73 & 2.60 \\
\hline & Monopotassium phosphate & 7.01 & 39.33 & 1.40 & 6.80 & 39.23 & 1.65 \\
\hline & Salicylic acid & 7.10 & 42.65 & 1.95 & 7.10 & 41.73 & 2.10 \\
\hline & Control & 6.99 & 38.00 & 1.32 & 6.50 & 36.50 & 1.62 \\
\hline \multirow[t]{4}{*}{ Control } & Amino acids & 6.97 & 36.33 & 0.80 & 6.75 & 37.73 & 1.32 \\
\hline & Monopotassium phosphate & 6.99 & 35.33 & 0.95 & 7.30 & 38.74 & 1.60 \\
\hline & Salicylic acid & 7.03 & 40.75 & 1.42 & 7.02 & 38.85 & 1.52 \\
\hline & Control & 6.94 & 33.75 & 0.72 & 6.00 & 35.50 & 0.80 \\
\hline LSD at $5 \%$ & & 0.13 & 230 & 0.82 & 0.66 & 2.95 & 0.22 \\
\hline
\end{tabular}


In this connection, using seaweed extract recorded the highest values in all tested chemical constituents followed by using calcium plus glutarie acid treatment without significant differences among them. On contrast, the lowest values in all measured fruit chemical quality traits were found in case of the control treatment and using humic acid without significant variation in most cases a among them . Obtained results may be due to the effect of seaweed extract and calcium plus glutaric acid on increasing photosynthetic pigments (Table 2) and inturn the formation of ingredient constituents used in assimilation of such chemical fruit constituents . obtained results are in agreement with those reported by Ashraf and Ewees ( 2008), Shafshak et al.( 2008), Fischer et al. ( 2009) in case of humic acid, Chen et al. (2003), Vernieri et al. (2006), Eyras et al. (2008), Sultana et al.(2009) and Rosalba et al. (2013) in case of seaweed extract, while Rab and Haq (2012), Lolaei (2012) and Abbasl, et al., (2013) in case of calcium and glutraic acid on tomato reported similar results.

\subsection{Effect of foliar spray treatments}

With regard to the effect of foliar spray treatments the same data in Table 5 show clearly that T.s.s.\%, vitamin C. content and total acidity $\%$ were significantly improved as a result of spraying the plants grown under salinity stress of the soil three times during the growth season by amine acids at 1 $\mathrm{ml} / \mathrm{L}$, monopotassium phosphate at $1 \mathrm{~g} / \mathrm{L}$ and salicylic acid at $1 \mathrm{~g} / \mathrm{L}$ compared to the control treatment. In addition, the highest values were noticed in case of using salicylic acid followed by using both of amino acid and monopotassium phosphate without significant differences among them in the two seasons of growth. In this respect, the superiority of salicylic acid may be attributed to its effect on photosynthetic assimilates through photosynthetic process which in turn effect on the chemical composition of fruit obtained results are coincided with those found by Hafez ( 2001), Shafshak et al.(2008), El-Tantawy (2009), El Desouky et al.( 2011) and Javaheri et al.(2012) in case of salicylic acid, Chapagain and Wiesman(2004) and Shafshak et al.(2008)in case of monopotassium phosphate on tomato reported similar results.

\subsection{Effect of the interaction}

As for the effect of the interaction, data in Table 5 show clearly that in monst cases the highest values of assayed fruit chemical constituents ( T.S.S., Vit. $\mathrm{C}$ and total acidity) were noticed as a result of the addition of seaweed extract combined with spraying the plants with salicylic acid during the two seasons of growth.

Finally it could be concluded that under such condition of soil salinity application of tested safety compared (humic acid, seaweed extract and calcium plus glutaric acid ) as soil addition and (amino acids, monopotassium phosphate and salicylic acid) as foliar spray can be recommended to alliviate the bad effect of soil salinity and increased growth, yield and quality of produced fruit .

References

A.O.A.C. 1990. Official methods of analysis. Association of official analytical chemists. 15th ed. Washington D.C., USA.

Abbasl, N.A., Z. Lubna, A.K.Hammad. and A.A.Qureshi. 2013. Effect of calcium chloride application on nutrient uptake,growth, yield and post harvest performance of tomato fruit .pak.J. Arid Agri., 45(5): 1581-1587 .

Achilea, O. 2002. Alleviation of salinity induced stress in cash crops by Multi K (Potassium Nitrate), five cases typifying the underlying pattern. Acta Hort.,573: 43-48.

Agong, S.G., Y. Yoshida, S. Yazawa and M. Masuda. 2004. Tomato response to salt stress. Acta Hort., 637: 93-97.

Ahmed, Y.M.A. 2003. Adaptation studies on increasing salt tolerance of mung bean plants. M.Sc.Thesis, Fac.Agric Zagazing Univ. (Benha Branch). ARE.

Ashraf, S.O. and M.S.A. Ewees.2008. The possible use of Humic acid incorporated with drip irrigation system to alleviate the harmful Effects of saline water on tomato plants . Fayoum J. Agric. Res Dev. ,22 (1): 52.70.

Bates, L.S., R.P. Waldern and I.D. Teare 1973. Rapid determination of free proline water stress studies. Plant and soil 39: 205-207.

Berlyn, G.P. and R.O. Russo. 1990. The use of organic biostimulants to promote root growth. Below ground Ecol., 2:12-13.

Brown, J.D. and O. Lilleland 1964. Rapid determination of potassium calcium and sodium in plant material and soil extracts flaw phosphorus. Proc.Amer.Soc. Hort. Sci, 48:341346.

Bynum, J.B., T. Cothern, R.G. Lemon, D.D. Fromme and R.I. Boma .2007. Field evaluation of nitrophenolate plant growth regulator (Chaperone) for the effect on cotton lint yield. J. Cotton Sci., 11:20-25.

Chapagain , B.P.and Z. Wiesman .2004. Effect of Nutri-Vant-Peak foliar spray on development , yield and fruit quality in green house tomatoes .Scientia Horticulturae 102 :177-188.

Chen, S.K., C.A. Edwards and S. Subler. 2003. The influence of two agricultural biostimulants on nitrogen transformations, microbial activity, and plant growth in soil microcosms. Soil Biol. Biochem., 35: 9-19.

Daneshmand, F., M.J.Arvin and K.Manouchehri.2009. Effect of acetylsalicylic acid on salt and osmatic stress tolerance in 
Solanum bulbacastanum in vitro. AmericanEurasian j. Agric. and Envir. Sci.,6(1):92-99.

Eata, A.E.K. 2001. Response of some tomato cultivars to natural soil salinity and use of some treatments to reduce salt injury. Ph.D. Thesis, Faculty of Agric. Mansoura Univ. ARE.

Economakis, C. and A. Daskalaki. 2003. Effect of potassium nutrition on yield and quality of tomato plants grown with nutrient film technique under sodium chloride saline conditions. Acta Hort., 609 : 337-339.

El-Desouky , S . A ., F .H .M . Ismaeil, A .L. Wanas, E .L .E . Fathy and M .M . Abd ElAll. 2011. Effect of Yeast Extract, Amino acid and citric acid on physioanatomical aspects and productivity of tomato plants grown in late summer season. Minufiya J . Agric.Res. 36(4):859-884.

El-Tantawy, E.M. 2009. Behaviour of tomato plants as affected by spraying with chitosan and aminofort as natural stimulator substances under application of soil organic amendments. Pakistan J. Biological Sci.,12(17): 1164-1173.

Eyras, M. C., G.E. Defosse and F. Dellatorre. 2008. Seaweed compost as an amendment for horticultural soils in patagonia, Argentina. Compost Science \& Utilization 16 (2): 119124.

Fischer. G.,C.A. Rodriguez and F.Casierra. Posach .2009. Reducing Negative effects of salinity in tomato (Solanum Lycopersicon L.) plants by adding Leonardite to soil . Acta Hort. 821:133-139.

Gehad, A. 2003. Deteriorated Soils in Egypt: Management and Rehabilitation. Executive Authority For Land Improvement Projects (EALIP), Ministry of Agriculture and land reclaimation, Egypt.

Hafez, M. R. 2001. Impact of some chemical treatments on salinity tolerance of some tomato cultivars. M.Sc. thesis, Fac. Agric., Ain Shams University.ARE

Hajer, A.S., A.A. Malibari, H.S. Al Zahrani and O.A. Almaghrabi. 2006. Responses of three tomato cultivars to seawater salinity Effect of salinity on the seedling growth. African J. Biotechnology, 5: 855-861.

Jameson, P.E. 1993. Plant hormones in the algae. Progress in Phycological Research . 9: 239-245.

Javaheri, M., K. Mashayekhi, A. Dad Khah and F.Z. Tavallaee.2012. Effect of salicylic acid on yield and quality characters of tomato fruit (Lycopersicon esculentum Mill. ). In tl. J.of.Agric . and crop Sci.4(16):1184-1187

John, M.K. 1970. Colorimetric determination of phosphorus in soil and plant material with ascorbic acid. Soil Sci., 109: 214-220.

Khan, N.A., S.Syeed, A. Masood, R. Nazar and N. Iqbal.2010. Application of salicylic acid increases contents of nutrients and antioxidative metabolism in mungbean and alleviates adverse effects of salinity stress. International J. Plant Biol.,29(3):162-190.

Li, Y. 2000. Analysis of greenhouse tomato production in relation to salinity and shoot environment. Ph.D. thesis, Wageningen Agricultural university. 95pp.

Lolaei, A. 2012. Effect of calcium chloride on growth and yield of tomato under sodium chloride stress. J. of Ornamental and Horticultural plants , 2(3): 155-160.

Neeraja, G., IP. Reddy, and B. Grantham. 2005. Effect of growth promoters on growth and yield of tomato cv. Marutham. J. Res. Angrau., 33:68-79.

Pregl, E. 1945. Quantitative organic micro analysis. $4^{\text {th }}$ Ed. J. Chundril, London.

Rab, A and I. Haq.2012. Foliar application of calcium chloride and borax influences plant growth, yield and quality of tomato (Lycopersicon esculentum Mill.) fruit Turk.J.Agric.,36 : 695-701.

Rady, M.M.2012. Anovel organo -mineral fertilizer can mitigate salinity strees effect for tomato production on reclaimed saline soil. South Africon j. of Botany 81:8.14

Rosalba, M.H., S.R. Fernando and G.H. Jeffrey.2013. Effect of liquid seaweed extract on growth of tomato seedlings. J. Appl.Phycol.,2: 21-29.

Rowell, D. L. 1995. Soil Science methods and application data. Library of Congress catalo ging publication data. New York, NY1058.USA.

Salehi, S., A.Khajehzadeh and F. Khorsandi.2011 .Growth of tomato as affect by foliar application of salicylic acid and salinity .American .Eurasian J.Agric .\& Environ. Sci., 11(4):564-567.

Schwab, W. and T. Raab. 2004. Developmental changes during strawberry fruit ripening and physico-chemical changes Production Practices and Quality Assessment of Food Crops, "Quality handling and Evolution", vol. 3kluwer Academic Publishers, Netherlands. pp. 341-369.

Shafshak , Nadia.S., S.M. Eid, H.S. Khafaga and Y. A .M Salma. 2008. Improving growth and productivity of tomato under saline conditions by fertilization and salinity hardening. J.Agric. Sci. Mansoura Univ.,33(11):7803.7815.

Shuqin, W.,Y.Kang, D.Wang, Sh.Liu and L.Feng.2007. Effect of drip irrigation with saline water on tomato (Lycopersicon esculentum Mill) yield and water use in semihumid area.Institute of Geographical Sci. and Natural Resource Res., BeiJing, China. 
Snedecor, G.W. and W.G. Cochran .1991. Statistical methods. $8^{\text {th }}$ Ed., Iowa state Univ. press, Iowa, USA.

Sultana, V., E. Sayed, J. Ara and A. Mohammad. 2009. Effect of brown seaweeds and pesticides on root rotting fungi and root knot nematode infecting tomato roots. J. of applied Botany and food quality. 83(1):50-53.

Tantawy, A. 2007. Effect of some mineral and organic compounds on salinity tolerance in tomato. Ph.D. thesis. Fac. Agric. Al Azhar Univ.ARE.
Vernieri, P., E. Tognoni, F. Borghesi, G. Serra, A. Ferrante and A. Piagessi. 2006. Use of biostimulants for reducing nutrient solution concentration in floating system. Acta Hortic. 718:477-484.

Yokoi, S., R.A. Bressan and P.M.Hasegawa.2002. Salt stress tolerance of plants. JIRCAS Working Report, 25-33.

Zahra,S.,B.Amin and Y.Mehdi.2010.The salicylic acid effect on the tomato (Lycopersicon esculentum Mill .) germination, growth and photosynthetic pigment under salinity stress (Nacl ).J.of stress Physiology \&Biochemistry 6(3):5-16.

\section{تأثير الإضافة الأرضية والرش الورقى ببعض المركبات الأمنة على نمو وانتاجية الطماطم النامية تحت ظروف الأراضى الملحية}

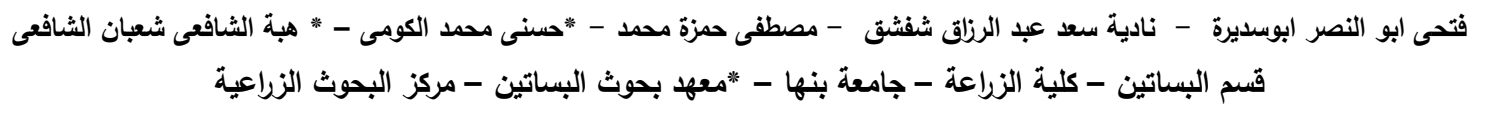

أجريت تجربتان حقليتان بمزرعة خاصة بقرية الحوة مركز بيلا محافظة كفر الثيخ خلال الموسم الصيفي لعامى 2013- 2014على

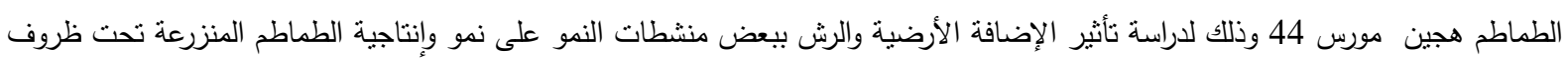

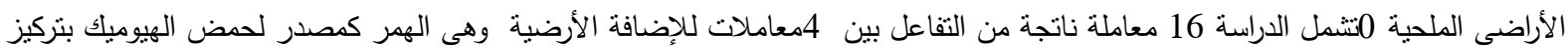
5جم /لتز والدبل ون كمصدر لمستخلص الطحالب البحرية بتركيز 5جم /لتر والفرى سال كمصدر للكالسيوم وحمض الجلوتاريك بتركيز 5مل/لتز بالإضافة للكنترول وكذللك 4 معاملات للرش وهى كالأتى الأمينو باور كمصدر للأحماض الأمينية 1مل/لتز والسورد كمصدر لحمض السلسيلك

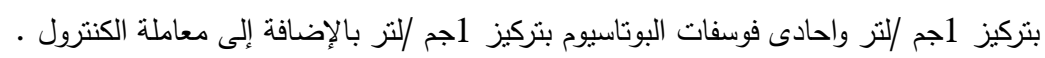

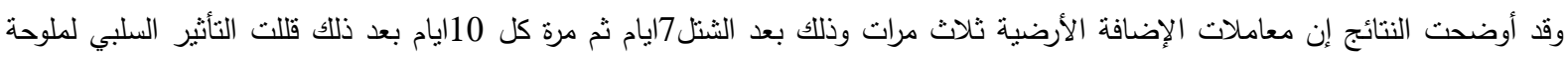
التربة وادى ذللك الى زيادة النمو الخضرى لنباتات الطماطم (طول النبات - عدد الأفرع والأوراق - الوزن الطازج والجاف وكذلك الندام المساحة الورقية للنبات)وكذللك أدى استخدام هذه المعاملات الى زيادة محتوى النباتات من الكلوروفيل الكلى والنيتروجين - الفسفور - الكالسيوم - البوتاسيوم والبرولين وقلل من تركيز الصوديوم فى المجموع الخضرى للنبات وكذلك ادت الى زيادة المحصول الكلى للنبات - الفدان - المحصول القابل

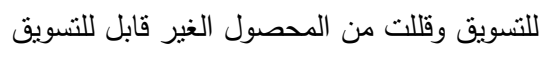
وأدت هذه المعاملات أيضا إلى تحسن صفات الجودة الطبيعية (متوسط وزن الثمرة طول وقطر الثمرة وصلابة الثمار ) و كذلك تحسين صفات

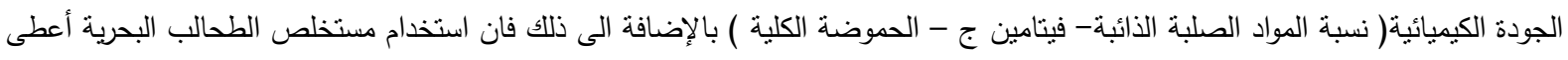
أفضل النتائج في هذا الاتجاه أما بالنسبة لمعاملات الرش فقد ادى الرش بالأحماض الامينية و حمض السلسيلك واحادى فوسفات البوتاسيوم إلى زيادة معنوية فى كلا من النمو الخضرى - التركيب الكيماوى -المحصول ومكوناته وصفات الجودة الطبيعية والكيميائية للنباتات.

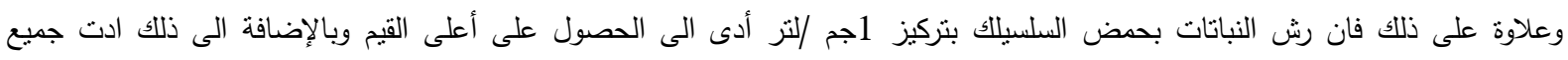

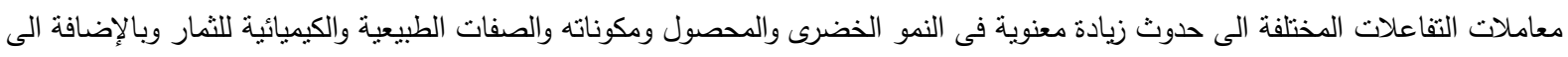
ذلك فان معاملة التفاعل بين الإضافة الأرضية بمستخلص الطحالب البحرية والرش بحمض السلسيلك كان لهما التأثير الأعلى فى هذا الإتجاه. 